\title{
Deoxyribonucleic Acid Relatedness Between Serratia plymuthica and Other Serratia Species, with a Description of Serratia odorifera sp. nov. (Type Strain: ICPB 3995)
}

\author{
P. A. D. GRIMONT, ${ }^{1}$ FRANCINE GRIMONT, ${ }^{1}$ C. RICHARD, ${ }^{1}$ B. R. DAVIS, ${ }^{2}$ A. G. STEIGERWALT,${ }^{2}$ AND \\ DON J. BRENNER ${ }^{2}$
}

\begin{abstract}
Enteric Section, Center for Disease Control, Atlanta, Georgia $30333,{ }^{2}$ and Service des Enterobactéries, Institut Pasteur, F.75724 Paris Cedex 15, France
\end{abstract}

\begin{abstract}
Seven new isolates of Serratia plymuthica (including two from a human source) and 24 isolates resembling unclustered Serratia strain 38 (Grimont et al., J. Gen. Microbiol 98:39-66, 1977) are described. Deoxyribonucleic acid relatedness studies, obtained with labeled reference deoxyribonucleic acid from S. plymuthica 392 confirm that $S$. plymuthica is a discrete species. Mean percent relatedness of $S$. plymuthica isolates to strain 392 was $88 \pm 13.6$ (standard deviation), whereas the mean percent relatedness of $S$. liquefaciens isolates (the closest species) to strain 392 was $52 \pm 12.4$. Strain 38 and twenty-four "38-like" isolates constitute a new deoxyribonucleic acid hybridization group that is 28 to $43 \%$ related to Serratia species and to the "Citrobacter-like" group of Leclerc and Buttiaux, and 15 to $22 \%$ related to other known species of Enterobacteriaceae. This 38-like group constitutes a new species that is named Serratia odorifera sp. nov. (type strain, ICPB 3995). Two biotypes ( 1 and 2) are described. Strains of this species will grow on caprylate-thallous agar (selective for Serratia spp.), and they have a characteristic odor. Most strains of $S$. odorifera were recovered from clinical specimens.
\end{abstract}

The taxonomy of the genus Serratia has changed markedly in the past few years. The 8th edition of Bergey's Manual of Determinative Bacteriology (23), following earlier work $(10,11,20)$, recognizes only one species, Serratia marcescens. However, since 1959 several workers $(1,12,14)$ have challenged the concept of a monospecific genus Serratia. The second species to be formally recognized was $S$. liquefaciens (Grimes and Hennerty 1931) Bascomb et al. 1971 $(1,13)$. A third species, S. rubidaea (Stapp 1940) Ewing et al. 1973, was proposed and corresponds to Serratia biotype 2 of Bascomb et al. (1) and to phenon B of Grimont and Dulong de Rosnay (14). The same taxon is also called $S$. marinorubra ZoBell and Upham 1944. The reasons for using $S$. marinorubra rather than $S$. rubidaea have been discussed by some of us elsewhere (16). Finally, a fourth species, S. plymuthica (Lehmann and Neumann 1896) Breed, Murray, and Hitchens $1948(2,18)$, has been reintroduced (16). S. plymuthica is phenetically closest to $S$. liquefaciens, from which it is differentiated by pigmentation, growth on quinate as the sole carbon source, and lack of lysine, ornithine decarboxylases, and tetrathionate reductase (16). Many additional strains appear to belong in the genus Serratia but are distinct from the four described species. One of these, strain 38 , was previously described (16).
Studies of deoxyribonucleic acid (DNA) relatedness among species of Serratia and Enterobacter (27) have shown that $S$. marcescens, $S$. liquefaciens, and S. rubidaea (S. marinorubra) are valid species. In this study we investigated the distinctness of S. plymuthica from S. liquefaciens and other Serratia spp. on the basis of DNA relatedness and described a group of strains that resemble Serratia sp. strain 38, which remained unclustered in a recent numerical taxonomic study (16).

\section{MATERIALS AND METHODS}

The strains used in this study are shown in Table 1. Organisms were maintained on meat extract agar or semisolid yeast extract-nutrient agar. Routine cultivation of organisms was carried out in brain heart infusion broth.

Carbon source utilization tests, pigment and odor production, growth at $4^{\circ} \mathrm{C}, \beta$-xylosidase test (with $o$ nitrophenyl- $\beta$-xyloside), tetrathionate reduction, Voges-Proskauer reaction as modified by Richard (21), gelatin hydrolysis (plate method), Tween hydrolysis, and chitin hydrolysis were carried out as described by Grimont et al. (16). The composition of caprylatethallous medium has been published (26). All other biochemical tests were carried out as described by Edwards and Ewing (8).

The medium used for labeling cells with ${ }^{32} \mathrm{PO}_{4}$, the preparation of both labeled and unlabeled DNA, and the shearing of DNA have been described $(4,6)$. In all 
TABLE 1. Origin of strains

\begin{tabular}{|c|c|c|c|}
\hline Strain no. & Biotype $^{a}$ & Source and history & References \\
\hline \multicolumn{4}{|c|}{$\begin{array}{l}\text { Strains identified as Serratia ply- } \\
\text { muthica: }\end{array}$} \\
\hline CDC 2000-73 & $\mathrm{C} 2 \mathrm{a}$ & Grimont 33 , Brisou 3617 , seawater & 16 \\
\hline CDC 2001-73 & $\mathrm{C} 2 \mathrm{a}$ & Grimont 34 , Brisou 3736 , unknown & 16 \\
\hline Grimont 299 & $\mathrm{C} 2 \mathrm{~b}$ & Brisou 6912 , seawater & 16 \\
\hline Grimont 392 & $\mathrm{C} 2 \mathrm{~b}$ & Spring water, centrotype of phenon $\mathrm{C} 2$ & 16 \\
\hline CDC $1286-57$ & $\mathrm{C} 2 \mathrm{~b}$ & M. Grimes, Ireland, milk & 27 \\
\hline CDC $2707-57$ & $\mathrm{C} 2 \mathrm{~b}$ & NCTC 8015 , NCIB 8285 , Grimont 517, water & 16 \\
\hline CDC 2708-57 & $\mathrm{C} 2 \mathrm{~b}$ & NCTC 8706 , NCIB 8266 , Grimont 516, soil & 16 \\
\hline CDC 2709-57 & $\mathrm{C} 2 \mathrm{~b}$ & NCTC 8900 , laboratory contaminant & \\
\hline CDC 3855-62 & $\mathrm{C} 2 \mathrm{~b}$ & $\begin{array}{l}\text { Le Minor 24-62, L. Le Minor, Institut Pasteur } \\
\text { (Paris) }\end{array}$ & \\
\hline $\mathrm{CDC} 1210-70$ & $\mathrm{C} 2 \mathrm{~b}$ & ATCC 15928 , source unknown & 9,16 \\
\hline CDC 462-75 & $\mathrm{C} 2 \mathrm{~b}$ & Sputum, Rhode Island & \\
\hline CDC $3513-75$ & $\mathrm{C} 2 \mathrm{~b}$ & Sputum, Colorado & \\
\hline Grimont 510 & $\mathrm{C} 2 \mathrm{c}$ & CCM 640 , ATCC 183 , type strain & 16 \\
\hline CDC $4743-70$ & $\mathrm{C} 2 \mathrm{c}$ & Y. Hamon, Institut Pasteur (Paris) & \\
\hline \multicolumn{4}{|c|}{$\begin{array}{l}\text { Strains identified as Serratia } \\
\text { odorifera sp. nov.: }\end{array}$} \\
\hline Grimont 38 & 1 & Cultivated mushroom, Bordeaux, France & 14,16 \\
\hline Grimont 1073 & 1 & Sputum, Bordeaux; ICPB 3995, holotype & \\
\hline CDC 4409-66 & 1 & Lung, Connecticut & \\
\hline CDC $3252-68$ & 1 & Throat, Pennsylvania & \\
\hline CDC 5112-69 & 1 & Bile, Connecticut & \\
\hline CDC 4321-70 & 1 & Sputum, California & \\
\hline CDC 4933-70 & 1 & Sputum, Colorado & \\
\hline CDC $1877-71$ & 1 & Sputum, Minnesota & \\
\hline CDC 5248-71 & 1 & Sputum, Colorado & \\
\hline CDC $3138-72$ & 1 & Throat, California & \\
\hline $\mathrm{CDC} 652-73$ & 1 & Sputum, New York & \\
\hline CDC 2985-73 & 1 & Mouth, Colorado & \\
\hline CDC 133-74 & 1 & Horse-bite, California & \\
\hline Richard 2-73 & 1 & Mussel, Saint-Etienne, France & \\
\hline Richard 17-74 & 1 & Blood, Lyon, France & \\
\hline Richard 12-76 & 1 & Pus, Paris & \\
\hline Richard 11-77 & 1 & Sputum, Paris & \\
\hline CDC 292-74 & 2 & Blood, California & \\
\hline CDC 2346-74 & 2 & Abdominal wound, Wisconsin & \\
\hline CDC 2861-74 & 2 & Tracheal secretion, California & \\
\hline CDC $3472-74$ & 2 & Blood, Massachusetts & \\
\hline CDC 1396-75 & 2 & Bronchial washing, Vermont & \\
\hline CDC $3567-75$ & 2 & Urine, New Jersey & \\
\hline CDC $1517-76$ & 2 & Tracheal exudate, Pennsylvania & \\
\hline CDC 1945-77 & 2 & Sputum, Maryland & \\
\hline \multicolumn{4}{|c|}{$\begin{array}{l}\text { Other strains used in DNA relat- } \\
\text { edness studies: }\end{array}$} \\
\hline \multicolumn{4}{|l|}{ S. liquefaciens } \\
\hline ATCC 14460 & Cld & Grimes, type strain & $16,24,27$ \\
\hline "E. liquefaciens" & Cld & Derived from ATCC 14460 & \\
\hline CDC 446-68 & Cld & Derived from ATCC 14460 & 27 \\
\hline CDC 6136-66 & Clb & Centrotype of phenon $\mathrm{C} 1$ (Grimont 275) & 16,27 \\
\hline CDC 1107-57 & & Dairy product, Minnesota & 27 \\
\hline CDC $1284-57$ & $\mathrm{Clb}$ & Milk, Cork, Ireland & 27 \\
\hline \multicolumn{4}{|l|}{ S. marcescens } \\
\hline SM6 & A2 & Walter Reed Army Institute of Research & 27 \\
\hline CDC 866-57 & A4 & Abscess & 27 \\
\hline CDC 868-57 & A4 & Urine & 27 \\
\hline CDC 5147-64 & & Blood, Pennsylvania & \\
\hline CDC 1201-65 & A5 & Stool, Kentucky & 27 \\
\hline
\end{tabular}


TABLE 1-Continued

\begin{tabular}{|c|c|c|}
\hline Strain no. & Source and history & References \\
\hline \multicolumn{3}{|l|}{ S. marinorubra (S. rubidaea) } \\
\hline CDC 4445-64 & Blood, Bruhl, Hamburg, Germany & 27 \\
\hline CDC 5474-68 & H. Lautrop, Copenhagen, Denmark & 27 \\
\hline CDC 4057-71 & Blood, Colorado & 27 \\
\hline CDC 934-72 & River, Maryland & 27 \\
\hline \multicolumn{3}{|l|}{ "Citrobacter-like" } \\
\hline CDC 4552-71 & H. Leclerc, Lille, France & 7 \\
\hline CDC 4554-71 & Leclerc, Lille, France & 7 \\
\hline $\begin{array}{l}\text { Enterobacter aerogenes CDC } \\
1627-66\end{array}$ & Sputum, Massachusetts & 27 \\
\hline \multicolumn{3}{|l|}{ Enterobacter cloacae } \\
\hline CDC $1347-71$ & Blood, Colorado & 27 \\
\hline $256-4(Y)$ & National Institutes of Health & 27 \\
\hline \multicolumn{3}{|l|}{ Hafnia alvei } \\
\hline \multicolumn{3}{|l|}{ CDC $5632-72$} \\
\hline CDC $329-73$ & Wound, Connecticut & \\
\hline \multicolumn{3}{|l|}{ CDC 4510-75 } \\
\hline Enterobacter sp. 76-01 & Urine, Clermont-Ferrand, France & 22 \\
\hline $\begin{array}{l}\text { Enterobacter agglomerans } \\
\text { CDC } 2780-70\end{array}$ & Wound, Washington & \\
\hline $\begin{array}{l}\text { Erwinia carotovora (Pectobac- } \\
\text { terium carotovorum) ATCC } \\
\quad 495\end{array}$ & Soft rot of carrot, Jones; co-type & 24 \\
\hline $\begin{array}{l}\text { Erwinia amylovora ICPB EA } \\
178\end{array}$ & M. P. Starr; ATCC 19381 & \\
\hline $\begin{array}{l}\text { Citrobacter freundii CDC } 460- \\
61\end{array}$ & Meat, South Carolina & \\
\hline Proteus mirabilis PR 14 & Center for Disease Control & \\
\hline Escherichia coli $\mathrm{K}-12$ & University of Washington, Seattle & \\
\hline
\end{tabular}

${ }^{a}$ Biotype of Serratia spp. according to Grimont et al. (16).

cases, $0.1 \mu \mathrm{g}$ of sheared, ${ }^{32} \mathrm{PO}_{4}$-labeled DNA per ml was reacted with $150 \mu \mathrm{g}$ of sheared, unlabeled DNA per $\mathrm{ml}$ of $0.28 \mathrm{M}$ phosphate buffer $(\mathrm{pH} 6.8$ ) for $16 \mathrm{~h}$ at 60 or $75^{\circ} \mathrm{C}$. After incubation, samples were diluted to $0.14 \mathrm{M}$ phosphate buffer, and sodium dodecyl sulfate was added to $0.4 \%$. Reassociated DNA was separated from unreacted DNA on hydroxyapatite by use of a batch procedure (5). Unreacted DNA did not bind to hydroxyapatite. The reassociated DNA bound to hydroxyapatite was eluted in a series of washes with 0.4 M phosphate buffer.

A homologous control and nine heterologous samples were processed simultaneously. Observed homologous DNA reassociation was arbitrarily deemed $100 \%$. Heterologous DNA reassociation was evaluated relative to that of homologous DNA reassociation.

In thermal elution experiments, the reassociated DNA bound to hydroxyapatite was eluted by increasing the temperature in $5^{\circ} \mathrm{C}$ increments. In this case, bound DNA is denatured and eluted from hydroxyapatite as the temperature exceeds the $T_{m(e)}$ (that temperature at which $50 \%$ of given double-stranded DNA is eluted from hydroxyapatite). $\Delta T_{m(e)}$ is the decrease in thermal elution midpoint between heterologous DNA reactions and the homologous DNA reaction. A $1^{\circ} \mathrm{C}$ decrease in thermal stability is assumed to result from about $1 \%$ unpaired bases (19). Hence, $\Delta T_{m(e)}$ allows one to estimate the percentage divergence within related sequences.

\section{RESULTS}

The computer data bank of the Enteric Section at the Center for Disease Control (CDC) was surveyed to detect any "atypical" Serratia or Enterobacter species that closely or loosely corresponded to the description of either S. plymuthica or the unclustered strain 38 of Grimont et al. (16). The selected strains were subjected to a number of biochemical tests (see above). Eleven of these strains were identified as $S$. plymuthica, and 19 were close to strain 38 and to a similar strain isolated in Bordeaux (no. 1073). Four strains resembling strain 38 (38-like) were independently identified at the Pasteur Institute (Paris). To avoid any confusion, 38-like strains will now be called Serratia odorifera sp. nov., a step which is justified in the Discussion.

Biochemical characteristics of the S. plymuthica strains are shown in Table 2. As several $S$. plymuthica strains identified at CDC had been also studied (under other collection numbers) by Grimont et al. (16), only characteristics of newly studied strains are listed in Table 2 . It can be seen that these strains can be assigned to one of the three biotypes described in S. plymuthica 
TABLE 2. Biochemical characters of CDC strains newly identified as Serratia plymuthica

\begin{tabular}{|c|c|c|c|c|c|c|c|}
\hline \multirow{2}{*}{ Biochemical character } & \multicolumn{7}{|c|}{ Reaction of CDC strains: } \\
\hline & $1286-57$ & $2709-57$ & $3855-62$ & $1210-70$ & $462-75$ & 3513-75 & $4743-70$ \\
\hline \multicolumn{8}{|l|}{ Carbon source utilization ${ }^{a}$} \\
\hline Acetate & $(+)$ & $(+)$ & $(+)$ & $(+)$ & $(+)$ & $(+)$ & - \\
\hline Aconitate & + & + & + & + & + & + & - \\
\hline Adonitol & - & - & - & - & - & - & - \\
\hline L-Arabinose & + & + & + & + & + & + & + \\
\hline D-Arabitol & - & - & - & - & - & - & - \\
\hline Benzoate & - & $(+)$ & - & - & - & - & - \\
\hline Betaine & - & - & - & - & - & - & - \\
\hline DL-Carnitine & - & - & - & - & - & - & - \\
\hline Cellobiose & + & + & + & + & + & + & + \\
\hline Erythritol & - & - & - & - & - & - & - \\
\hline Glycerol & + & + & + & + & + & + & - \\
\hline Histamine & - & - & - & - & - & - & - \\
\hline 3-Hydroxybenzoate & - & - & - & - & - & - & - \\
\hline 4-Hydroxybenzoate & $\stackrel{+}{(+)}$ & - & - & $(+)$ & $\stackrel{+}{(+)}$ & $\stackrel{+}{(+)}$ & $(+)$ \\
\hline Melibiose & + & + & + & + & + & + & + \\
\hline$\alpha$-Methyl glucoside & $(+)$ & $(+)$ & + & - & $(+)$ & + & $(+)$ \\
\hline Mucate & - & - & - & - & + & + & + \\
\hline Nicotinate & - & - & + & + & + & + & + \\
\hline L-Ornithine & - & - & - & - & - & - & - \\
\hline Quinate & + & + & + & + & + & + & + \\
\hline Rhamnose & - & - & - & - & + & - & - \\
\hline Sorbitol & - & - & - & - & + & + & + \\
\hline D-Tartrate & - & - & - & - & - & - & - \\
\hline Trigonelline & - & - & - & - & - & - & - \\
\hline Pigment (red) & - & + & + & - & - & - & + \\
\hline Odor "38-like" & - & - & - & - & - & - & - \\
\hline$\beta$-Xylosidase (ONPX) ${ }^{b}$ & + & - & + & $(+)$ & - & - & + \\
\hline Tetrathionate reduction & - & - & - & - & - & - & - \\
\hline Lysine decarboxylase & - & - & - & - & - & - & - \\
\hline Arginine dihydrolase & - & - & - & - & - & - & - \\
\hline Ornithine decarboxylase & - & - & - & - & - & - & - \\
\hline Gas from glucose & - & - & + & + & - & - & + \\
\hline Growth at $4^{\circ} \mathrm{C}^{c}$ & + & + & + & + & + & + & $(+)$ \\
\hline
\end{tabular}

$a$, Growth in 1 to 4 days; (+), growth in 5 to 14 days.

${ }^{b}+$, Positive in $2 \mathrm{~h} ;(+)$, positive in $24 \mathrm{~h}$.

$c+$, Good growth in 4 days; $(+)$, good growth in 5 to 10 days.

(16). It is interesting that two strains (CDC 46275 and 3513-75) were recovered from human sputum.

Biochemical characteristics of $S$. odorifera (38-like strains) are listed in Table 3. Two biotypes were distinguished. Strains of biotype 1 can grow on sucrose and ornithine but not on erythritol (as the sole carbon source), and have an ornithine decarboxylase, whereas biotype 2 strains give the opposite reactions in these tests.

All $S$. odorifera strains are gram-negative, peritrichous rods that grow well on ordinary media (e.g., nutrient agar), ferment D-glucose (without production of gas), are oxidase negative, and reduce nitrates to nitrites. They clearly are members of the family Enterobacteriaceae (8).
$S$. odorifera strains are not pigmenied. However, they grow on the caprylate-thallous selective medium for Serratia (26) and hydrolyze gelatin, corn oil, and DNA but not Tween 80 or chitin. With rare exceptions, on most agar media (e.g., brain heart, Trypticase soy, nutrient, Mueller-Hinton) they give off a characteristic odor that resembles the smell of vegetable matter (14, 16).

S. odorifera biotype 1 includes strain 38 , which was close to the genus Serratia by numerical taxonomy (16).

A characteristic of $S$. odorifera that may be of practical importance is the variability of results with both indole and Voges-Proskauer tests. Indole production was often scored "weak," and different methods produced differ- 
ent results for acetoin production. Only the Richard method (21) seemed sensitive enough to detect acetoin production reproducibly.

Results of DNA relatedness studies obtained with labeled reference DNA from S. plymuthica 392 and from $S$. odorifera 1073 are shown. in Table 4.

The main question about $S$. plymuthica was whether it could be distinguished from $S$. liquefaciens. S. plymuthica strains were more than $73 \%$ related to strain 392 at $60^{\circ} \mathrm{C}$. At $75^{\circ} \mathrm{C}$ relatedness did not drop below 52\%. For the least related strain of this species (2001-73), divergence was only $4.7 \%$. Relatedness of $S$. liquefaciens strains to $S$. plymuthica 392 was lower and did not exceed $60 \%\left(\right.$ at $60^{\circ} \mathrm{C}$ ). At $75^{\circ} \mathrm{C}$, this relatedness dropped significantly (to $31 \%$ or lower), and divergence was about $9.8 \%$. This is clearly illustrated by thermal elution profiles of DNA duplexes (Fig. 1). The thermal elution profiles (with S. plymuthica 392 labeled DNA) were almost superposable when the unlabeled DNA was from either $S$. plymuthica 392 (the centrotype of phenon $\mathrm{C} 2$, reference 16 ) or $S$. plymuthica 510 (the type strain isolated in 1887). $T_{m(e)}$ values were respectively 91 and $90.4^{\circ} \mathrm{C}$. However, when the unlabeled DNA was from either $S$. liquefaciens 14460 (the type strain) or $S$. liquefaciens 6136-66 (the centrotype of phenon $\mathrm{C} 1$, reference 16 ), the thermal elution profiles shifted toward lower temperatures. $T_{m(e)}$ values were $81.3^{\circ} \mathrm{C}$ for both duplexes.

Other species of Serratia were 26 to $53 \%$ related to S. plymuthica and non-Serratia species showed less than $20 \%$ relatedness. The exception was the "Citrobacter-like" group of Leclerc and Buttiaux $(7,17)$, which showed relatedness to $S$. plymuthica similar to that of other Serratia species. A summary of relatedness values of Serratia species (plus the "Citrobacter-like" group) to S. plymuthica 392 is shown with calculated standard deviations in Table 5 . These standard deviations, taking into account intrastrain (reproducibility) and interstrain (homogeneity) variations, allow a better interpretation of DNA relatedness values.

Members of S. odorifera were 60 to $98 \%$ related to strain 1073. Related sequences showed little divergence $(0.3$ to $4.0 \%)$, and the relative binding at $75^{\circ} \mathrm{C}$ was at least $58 \%$. Strains assigned to biotype 1 were more related to strain 1073 (over $70 \%$ ) than were the strains of biotype $2(60$ to $69 \%$ ). However, the stability of reassociated sequences supports inclusion of biotype 2 strains in the same hybridization group with biotype 1 . The average relative binding of DNA from all previously known Serratia species and of Citrobacter-like group to S. odorifera 1073 was found in the range of 31 to $38 \%$. The most related strain studied was $S$. liquefaciens 6136 66 (centrotype), with $43 \%$ relatedness to strain 1073. The lowest relatedness of a Serratia strain to 1073 was that of $S$. marcescens $868-57$ (28\% relatedness). Members of other genera, except for the Citrobacter-like group, were not closely related to $S$. odorifera 1073 . Divergence of related sequences in S. odorifera/other Serratia spp. hybridizations was in the range of 10 to $13 \%$.

\section{DISCUSSION}

These results of DNA relatedness correlate well with those obtained by numerical taxonomy (16). Both types of data confirm that S. plymuthica and $S$. liquefaciens, although closely related, are distinct both phenetically and genetically. They also have different proteinase patterns in agar gel electrophoresis (15). S. marcescens is next most closely related to $S$. plymuthica, followed by the Citrobacter-like group, and finally by $S$. marinorubra. When the reference labeled DNA is from $S$. liquefaciens or $S$. marcescens (27), $S$. marinorubra is also the most distant Serratia species. These relationships among Serratia species, based on relatedness of DNA, are in complete agreement with phenetic data (16). Strain 1286-57 of Steigerwalt et al. (27), labeled $S$. liquefaciens, is now identified as $S$. plymuthica. When its DNA was compared with labeled DNA from $S$. liquefaciens 446-68, a low percent relatedness was found at $75^{\circ} \mathrm{C}$, and divergence was as high as $9.8 \%$ (27). Recognition of S. plymuthica as a separate species from $S$. liquefaciens reduces the heterogeneity of $S$. liquefaciens that was apparent in the study of Steigerwalt et al. (27).

S. plymuthica has probably no clinical significance for humans. Among several thousand Serratia spp. identified at the $\mathrm{CDC}$ during the last 20 years, only two isolates of S. plymuthica were from humans. The major habitat of $S$. plymuthica is probably water (16).

The 25 strains that resemble strain 38 share a number of common biochemical characteristics, and the two biotypes differ in only four tests. Although DNA relatedness data at $60^{\circ} \mathrm{C}$ reflect this subdivision into two biotypes, DNA duplexes are stable (low percent divergence). These 25 strains constitute one hybridization group clearly distinct from 17 others included in this study. We conclude that these 38-like strains constitute a discrete bacterial species.

The hybridization groups closest to the 38-like species are Serratia spp. and the Citrobacter- 
TABLE 3. Biochemical characteristics of Serratia odorifera ${ }^{a}$

\begin{tabular}{|c|c|c|c|}
\hline Characteristic & Biotype 1 & Biotype 2 & Strain(s) with opposite sign \\
\hline No. of strains & 17 & 8 & \\
\hline \multicolumn{4}{|l|}{ Carbon source utilization } \\
\hline Aconitate & $+^{c} 17^{d}$ & +8 & \\
\hline $\begin{array}{l}\text { Adonitol } \\
\text { D-Alanine }\end{array}$ & $\begin{array}{l}+17 \\
+17\end{array}$ & $\begin{array}{l}+8 \\
+8\end{array}$ & \\
\hline $\begin{array}{l}\text { D-Alanine } \\
\text { L-Alanine }\end{array}$ & $\begin{array}{l}+17 \\
+17\end{array}$ & $\begin{array}{l}+8 \\
+8\end{array}$ & \\
\hline $\begin{array}{l}\text { L-Alanine } \\
\text { 4-Aminobutyrate }\end{array}$ & $+16(1)^{e}$ & $+7(1)$ & \\
\hline L-Arabinose & $+\overline{17}$ & +8 & \\
\hline D-Arabitol & -0 & -0 & \\
\hline Benzoate & -0 & -0 & \\
\hline Betaine & -0 & -0 & \\
\hline Caprylate & $+12(5)$ & +8 & \\
\hline DL-Carnitine & -0 & -0 & \\
\hline D-Cellobiose & +17 & +8 & \\
\hline meso-Erythritol & -0 & +8 & \\
\hline D-Glucosamine & +17 & +8 & \\
\hline Histamine & -0 & -0 & \\
\hline 3-Hydroxybenzoate & -0 & -0 & \\
\hline 4-Hydroxybenzoate & -0 & -0 & \\
\hline Kynurenate & +17 & +8 & \\
\hline D-Lactose & $(+) 2(15)$ & $(+) 1(7)$ & \\
\hline Maltose & +17 & +8 & \\
\hline D-Melibiose & +17 & $+7(1)$ & \\
\hline$\alpha$-Methyl glucoside & -0 & -0 & \\
\hline $\begin{array}{l}\text { Mucate } \\
\text { Nicotinate }\end{array}$ & +17 & $+7(1)$ & \\
\hline $\begin{array}{l}\text { Nicotinate } \\
\text { L-Ornithine }\end{array}$ & $\begin{array}{l}+14(3) \\
(+)(13)\end{array}$ & $\begin{array}{l}+6(1) \\
-0\end{array}$ & $\begin{array}{l}3472-74 \\
5248-71,3138-72,2-73,17-74\end{array}$ \\
\hline L-Proline & $\begin{array}{l}17 \\
+17\end{array}$ & +8 & \\
\hline Putrescine & +17 & +8 & \\
\hline Quinate & -0 & -0 & \\
\hline L-Rhamnose & +17 & $+5(3)$ & \\
\hline D-Sorbitol & +17 & +8 & \\
\hline Sucrose & +16 & -0 & $1877-71$ \\
\hline D-Tartrate & (+) $2(15)$ & $(+)(6)$ & $292-74,1945-77$ \\
\hline Trigonelline & +17 & +8 & \\
\hline D-Tyrosine & +17 & +8 & \\
\hline \multicolumn{4}{|l|}{$\begin{array}{l}\text { Growth on caprylate-thallous } \\
\text { agar }\end{array}$} \\
\hline $\begin{array}{l}\text { agar } \\
\text { Pigment }\end{array}$ & -0 & -0 & \\
\hline Odor "38-like" & +15 & +7 & $2-73,17-74 ; 2346-74$ \\
\hline Motility & +17 & +7 & 2861.74 \\
\hline Growth at $4^{\circ} \mathrm{C}$ & $+15(2)$ & +8 & \\
\hline Oxidase & -0 & -0 & \\
\hline ONPG ( $\beta$-galactosidase) & $(+) 8(9)$ & $(+) 4(4)$ & \\
\hline ONPX ( $\beta$-xylosidase $)$ & $+16(1)$ & +8 & \\
\hline Tetrathionate reduction & -0 & -0 & \\
\hline Indole & $(+)(13)$ & $(+)(5)$ & $\begin{array}{l}3252-68,3138-72,38,652-73 ; 2861-74 \\
3472-74,2346-74\end{array}$ \\
\hline Methyl red & $(+)(17)$ & $(+)(8)$ & \\
\hline Voges-Proskauer & $-(7)$ & $(+)(7)$ & $\begin{array}{l}4321-70,652-73,2985-73,2-73,17-74,12- \\
\quad 76,11-77 ; 2861-74\end{array}$ \\
\hline Voges-Proskauer (Richard) & $+11(5 w)$ & $+7(1 w)$ & $3138-72$ \\
\hline Citrate (Simmons) & $(+) 4(6)$ & $(+) 1(4)$ & $\begin{array}{l}3252-68,4321-70,1877-71,5248-71,3138- \\
72,133-74,38 ; 2346-74,3567-75,1517 \\
76\end{array}$ \\
\hline $\mathrm{H}_{2} \mathrm{~S}$-triple sugar iron & -0 & -0 & \\
\hline Urea & $-1 w$ & -0 & $17-74$ \\
\hline Phenylalanine & -0 & -0 & \\
\hline Lysine decarboxylase & +17 & +8 & \\
\hline Arginine dihydrolase & -0 & -0 & \\
\hline
\end{tabular}


TABLE 3-Continued

\begin{tabular}{|c|c|c|c|}
\hline Characteristic & Biotype 1 & Biotype 2 & Strain(s) with opposite sign ${ }^{b}$ \\
\hline Ornithine decarboxylase & $+15(1)$ & -0 & $5248-71$ \\
\hline Malonate & -0 & -0 & \\
\hline $\mathrm{KCN}$ & $+7(3)$ & -1 & $\begin{array}{l}4409-66,3252-68,5112-69,4321-70,4933- \\
\quad 70,1877-71,5248-71 ; 292-74\end{array}$ \\
\hline Nitrate & +17 & +8 & \\
\hline & $\begin{array}{l}+16 \\
+16(1 w)\end{array}$ & $\begin{array}{l}+8 \\
+8\end{array}$ & 38 \\
\hline $\begin{array}{l}\text { Gelatin (plate method) } \\
\text { Tween } 40\end{array}$ & $\begin{array}{l}+16(1 \mathrm{w}) \\
(+\mathrm{w})(15)\end{array}$ & $\begin{array}{l}+8 \\
(+w)(7)\end{array}$ & $38,17-74 ; 2346-74$ \\
\hline $\begin{array}{l}\text { Tween } 40 \\
\text { Tween } 60\end{array}$ & $(+w)(13)$ & $-(1 \mathrm{w})$ & $38,1073,17-74,11-77 ;(292-74)$ \\
\hline Tween 80 & -0 & -0 & \\
\hline Corn oil & $-5(2)$ & +8 & $\begin{array}{l}3252-68, \quad(5112-69), \quad 4321-70, \quad 1877-71, \\
2985-73,(133-74), 2-73\end{array}$ \\
\hline Deoxyribonuclease & +17 & +8 & \\
\hline Chitin & -0 & -0 & \\
\hline Pectate & -0 & -0 & \\
\hline Gluconate test & +17 & +8 & \\
\hline Iodoacetate test & +17 & +8 & \\
\hline $\begin{array}{l}\text { Glucose fermentation } \\
\text { (oxidation/fermentation) }\end{array}$ & +17 & +8 & \\
\hline Glucose, gas & -0 & -0 & \\
\hline Acid from: & & & \\
\hline Lactose & $(+)(16)$ & $(+)(8)$ & 4409-66 \\
\hline Sucrose & $+16(1)$ & -0 & \\
\hline Mannitol & +17 & $+7(1)$ & \\
\hline Dulcitol & -0 & -0 & \\
\hline Salicin & +17 & $(+)(7)$ & 1396.75 \\
\hline Adonitol & $(+)(9)$ & $(+) 1(4)$ & $\begin{array}{l}1073,5112-69,4321-70,1877-71,5248-71 \\
\quad 652-73,2985-73,133-74 ; 2861-74,1396- \\
\quad 75,1517-76\end{array}$ \\
\hline Inositol & $(+) 6(9)$ & $+6(2)$ & $5112-69,4933-70$ \\
\hline Sorbitol & +17 & +8 & \\
\hline Arabinose & +17 & +8 & \\
\hline Raffinose & +17 & $-(2)$ & $2346-74,1945-77$ \\
\hline Rhamnose & $+13(3)$ & $+5(2)$ & $652-73 ; 1396.75$ \\
\hline Maltose & $+16(1)$ & +8 & \\
\hline Xylose & +17 & +8 & \\
\hline Trehalose & +17 & +8 & \\
\hline Cellobiose & +17 & +8 & \\
\hline$\alpha$-Methyl glucoside & -0 & -0 & \\
\hline Erythritol & -0 & $(+)(6)$ & $292.74,3567.75$ \\
\hline Melibiose & +17 & $+7(1)$ & \\
\hline D-Arabitol & -0 & $-(1)$ & $1396-75$ \\
\hline Mannose & +17 & +8 & \\
\hline Glycerol & $(+)(12)$ & $(+) 1(6)$ & $\begin{array}{l}3252-68,5248-71,652-73,2985-73,133-74 \\
\quad 1396-75\end{array}$ \\
\hline $\begin{array}{l}\text { Esculin } \\
\text { Mucate }\end{array}$ & $\begin{array}{l}+17 \\
-(5)\end{array}$ & $\begin{array}{l}(+)(4) \\
-1(3)\end{array}$ & $\begin{array}{l}292-74,3472-74,3567-75,1517-76 \\
(3252-68,1877-71,3138-72,652-73,2985- \\
73) ; 292-74,(2861-74,1517-76,2346-74)\end{array}$ \\
\hline $\begin{array}{l}\text { Tartrate (Jordan) } \\
\text { Acetate }\end{array}$ & $\begin{array}{l}+17 \\
(+)(9)\end{array}$ & $\begin{array}{l}+8 \\
(+)(5)\end{array}$ & $\begin{array}{l}38,1073,5112-69,4321-70,4933-70,3138- \\
72, \quad 2985-73,133-74 ; 292-74,1517-76, \\
1945-77\end{array}$ \\
\hline
\end{tabular}

${ }^{a}$ Parentheses indicate delayed reaction: Carbon source utilization tests, growth in 5 to 14 days; Tweens, precipitation in 5 to 10 days; other tests, positive in 2 to 4 days. Abbreviation: w, weak reaction.

${ }^{b}$ Strains that gave a reaction different from that indicated for their respective biotype. Biotype 1 strain numbers are in roman type; biotype 2 strain numbers are in italic type.

${ }^{c}$ Symbols: + , most strains positive; $(+)$, most strains delayed positive; - , most strains negative.

${ }^{d}$ Number of positive reactions (excluding delayed positive).

e Number of delayed positive reactions. 
TABLE 4. Reassociation of DNA from Serratia plymuthica 392 and S. odorifera 1073

\begin{tabular}{|c|c|c|c|c|c|c|}
\hline \multirow{3}{*}{ Source of unlabeled DNA } & \multicolumn{3}{|c|}{ S. plymuthica 392} & \multicolumn{3}{|c|}{ S. odorifera 1073} \\
\hline & \multicolumn{2}{|c|}{ \% Relative binding } & \multirow{2}{*}{$\begin{array}{l}\Delta T_{m(\text { e) }} \\
\text { at } 60^{\circ} \mathrm{C}\end{array}$} & \multicolumn{2}{|c|}{ \% Relative binding } & \multirow{2}{*}{$\begin{array}{l}\Delta T_{m(e)} \\
\text { at } 60^{\circ} \mathrm{C}\end{array}$} \\
\hline & $60^{\circ} \mathrm{C}$ & $75^{\circ} \mathrm{C}$ & & $60^{\circ} \mathrm{C}$ & $75^{\circ} \mathrm{C}$ & \\
\hline \multicolumn{7}{|l|}{ S. plymuthica } \\
\hline 392 & 100 & 100 & 0 & $38 \pm 5.0$ & 16 & \\
\hline 299 & $91 \pm 7.5$ & 81 & & $37 \pm 3.0$ & 16 & \\
\hline 510 & $100 \pm 5.7$ & 85 & 0.6 & $36 \pm 6.2$ & 13 & 10.8 \\
\hline $1286-57$ & $88 \pm 13.1$ & 69 & & $40 \pm 2.5$ & 10 & \\
\hline $3855-62$ & $85 \pm 19.5$ & 71 & & $40 \pm 9.7$ & 14 & \\
\hline $1210-70$ & $82 \pm 6.3$ & 77 & & $39 \pm 7.8$ & 13 & \\
\hline 4743-70 & $103 \pm 1.1$ & 83 & & $38 \pm 4.0$ & 15 & \\
\hline $2000-73$ & $86 \pm 3.8$ & 53 & & $36 \pm 2.6$ & 14 & \\
\hline $2001-73$ & $73 \pm 5.2$ & 52 & 4.7 & $36 \pm 2.0$ & 12 & \\
\hline $462-75$ & $83 \pm 17.6$ & 65 & & $40 \pm 4.4$ & 15 & \\
\hline $3513-75$ & $88 \pm 7.9$ & 88 & & $34 \pm 1.5$ & 15 & \\
\hline \multicolumn{7}{|l|}{ S. odorifera (biotype 1) } \\
\hline 1073 & $36 \pm 4.9$ & 14 & 12.9 & 100 & 100 & $\mathbf{0}$ \\
\hline 38 & $36 \pm 4.9$ & 12 & & $98 \pm 1.0$ & 98 & 0.3 \\
\hline $4409-66$ & $36 \pm 3.6$ & 13 & & $70 \pm 3.0$ & 85 & \\
\hline $3252-68$ & $41 \pm 9.0$ & 11 & & $96 \pm 4.4$ & 91 & \\
\hline $4321-70$ & $41 \pm 10.0$ & 12 & & $79 \pm 4.9$ & 115 & \\
\hline $5248-71$ & $34 \pm 1.0$ & 10 & & $71 \pm 3.1$ & 95 & \\
\hline $652-73$ & $35 \pm 2.5$ & 15 & & $81 \pm 5.5$ & 107 & \\
\hline \multicolumn{7}{|l|}{ S. odorifera (biotype 2) } \\
\hline $292-74$ & $35 \pm 6.0$ & 11 & & $60 \pm 5.2$ & 62 & 4.0 \\
\hline $1396-75$ & $34 \pm 3.8$ & 11 & & $69 \pm 1.5$ & 58 & \\
\hline $3567-75$ & $37 \pm 4.5$ & 10 & & $69 \pm 7.5$ & 64 & \\
\hline $1517-76$ & $36 \pm 2.6$ & 12 & & $67 \pm 5.5$ & 59 & \\
\hline \multicolumn{7}{|l|}{ S. liquefaciens } \\
\hline 14460 & $59 \pm 3.2$ & 23 & 9.8 & $31 \pm 4.6$ & 12 & 13.3 \\
\hline "E. liquefaciens" & $60 \pm 12.5$ & 27 & & $33 \pm 6.8$ & 11 & \\
\hline $446-68$ & $49 \pm 2.1$ & 22 & & $33 \pm 6.8$ & 5 & \\
\hline $6136-66$ & $58 \pm 6.7$ & 31 & 9.7 & $43 \pm 5.9$ & 9 & 11.3 \\
\hline $1107-57$ & $53 \pm 0.7$ & - & & $39 \pm 0.7$ & - & \\
\hline $1284-57$ & $31 \pm 2.1$ & - & & $36 \pm 0.7$ & - & \\
\hline \multicolumn{7}{|l|}{ S. marcescens } \\
\hline SM6 & $53 \pm 8.7$ & 27 & 8.1 & $31 \pm 9.3$ & 20 & 10.4 \\
\hline $866-57$ & $43 \pm 3.5$ & 23 & & $29 \pm 8.5$ & 15 & \\
\hline $868-57$ & $36 \pm 8.7$ & 22 & & $28 \pm 2.6$ & 15 & \\
\hline $5147-64$ & $47 \pm 6.6$ & 26 & 10.2 & $34 \pm 2.1$ & 17 & \\
\hline $1201-65$ & $46 \pm 3.1$ & 26 & & $34 \pm 7.0$ & 17 & 11.5 \\
\hline \multicolumn{7}{|l|}{ S. marinorubra (S. rubidaea) } \\
\hline $4445-64$ & $29 \pm 3.1$ & 15 & & $31 \pm 6.0$ & 15 & \\
\hline $5474-68$ & $31 \pm 3.1$ & 13 & & $34 \pm 10.4$ & 15 & \\
\hline $4057-71$ & $30 \pm 3.2$ & 14 & 8.8 & $35 \pm 4.0$ & 20 & 10.0 \\
\hline 934-72 & $26 \pm 1.7$ & 13 & & $29 \pm 3.6$ & 15 & \\
\hline \multicolumn{7}{|l|}{ "Citrobacter-like" } \\
\hline $4552-71$ & $36 \pm 2.5$ & 6 & & $36 \pm 8.1$ & 8 & 13.0 \\
\hline $4554-71$ & $33 \pm 3.1$ & 12 & 14.2 & $40 \pm 4.9$ & 10 & \\
\hline $\begin{array}{c}\text { Enterobacter aerogenes } \\
\quad 1627-66\end{array}$ & $15 \pm 3.5$ & & & $15 \pm 0.7$ & & \\
\hline Enterobacter cloacae & & & & & & \\
\hline $1347-71$ & $17 \pm 4.2$ & & & $22 \pm 4.9$ & & \\
\hline $256-4(Y)$ & $13 \pm 6.4$ & & & $20 \pm 0.0$ & & \\
\hline $\begin{array}{c}\text { Enterobacter agglomerans } \\
2780-70\end{array}$ & $12 \pm 2.1$ & & & $18 \pm 0.7$ & & \\
\hline $\begin{array}{l}\text { Enterobacter sp. 76-01 } \\
\text { Hafnia alvei }\end{array}$ & $15 \pm 1.4$ & & & $12 \pm 3.5$ & & \\
\hline $5632-72$ & $16 \pm 4.2$ & & & $20 \pm 2.8$ & & \\
\hline $329-73$ & $15 \pm 0.7$ & & & $21 \pm 2.8$ & & \\
\hline $4510-75$ & $14 \pm 0.0$ & & & $17 \pm 0.7$ & & \\
\hline Erwinia carotovora 495 & $15 \pm 1.4$ & & & $19 \pm 2.8$ & & \\
\hline Erwinia amylowora EA 178 & $16 \pm 0.7$ & & & $17 \pm 1.4$ & & \\
\hline Citrobacter freundii $460-61$ & $19 \pm 4.2$ & & & $18 \pm 2.1$ & & \\
\hline Proteus mirabilis PR 14 & $7 \pm 2.1$ & & & $7 \pm 2.1$ & & \\
\hline Escherichia coli K-12 & $10 \pm 2.8$ & & & $18 \pm 3.5$ & & \\
\hline
\end{tabular}




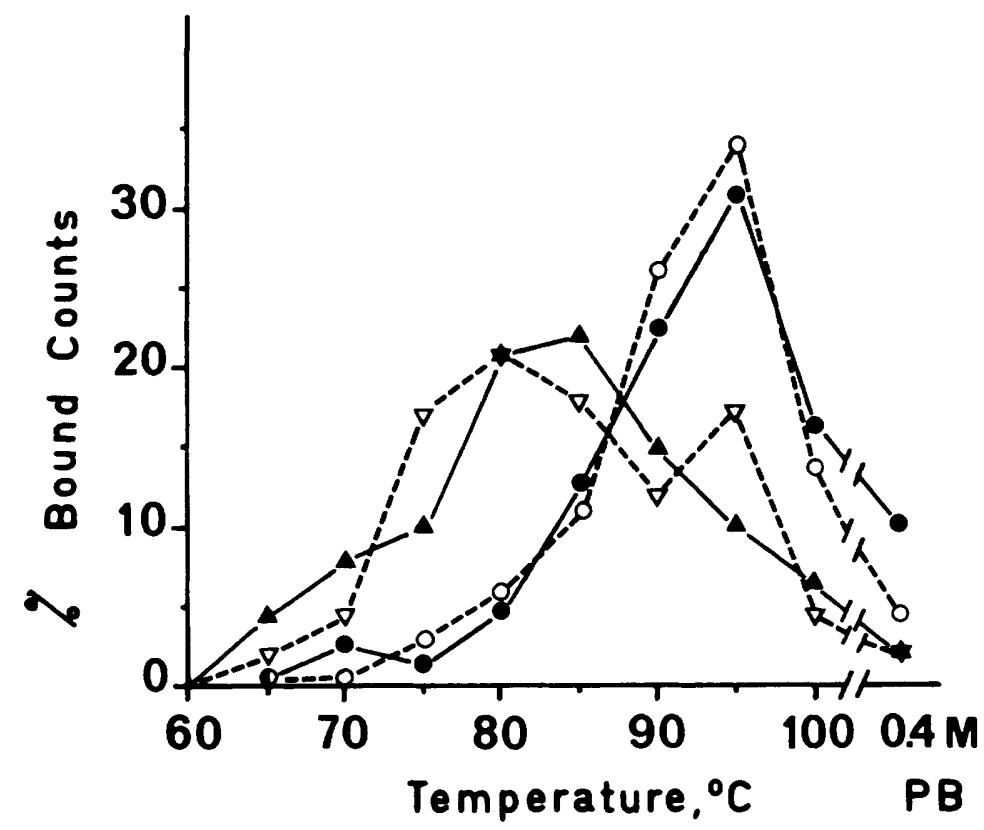

FIG. 1. Thermal elution profiles of Serratia plymuthica 392 DNA duplexes. ${ }^{32} P$-labeled DNA from S. plymuthica 392 was incubated with unlabeled DNA from S. plymuthica $392(0)$, S. plymuthica $510(0), S$. liquefaciens $C D C$ 6136-66 (A), and S. liquefaciens ATCC $14460(\Delta)$. Incubations were carried out in $0.14 M$ phosphate buffer $(\mathrm{PB})$ at $60^{\circ} \mathrm{C}$. After incubation the reaction mixtures were added to a test tube held at $60^{\circ} \mathrm{C}$ and containing $10 \mathrm{ml}$ of packed hydroxyapatite and subjected to thermal batch chromatography on hydrox. yapatite and assayed as described in the text.

TABLE 5. Summary of reassociation of DNA at $60^{\circ} \mathrm{C}$ from S. plymuthica 392 and S. odorifera 1073

\begin{tabular}{|c|c|c|}
\hline \multirow{2}{*}{ Species } & \multicolumn{2}{|c|}{ Mean $\%$ relative binding $\pm \mathrm{SD}^{a}$} \\
\hline & S. plymuthica 392 & S. odorifera 1073 \\
\hline $\begin{array}{l}\text { Serratia odorifera }{ }^{b} \\
\text { S. plymuthica } \\
\text { S. liquefaciens } \\
\text { S. marcescens } \\
\text { S. marinorubra (S. rubidaea) } \\
\text { "Citrobacter-like" }\end{array}$ & $\begin{array}{l}36 \pm 6.0 \\
88 \pm 13.6 \\
52 \pm 12.4 \\
45 \pm 9.0 \\
29 \pm 3.5 \\
35 \pm 3.5\end{array}$ & $\begin{array}{l}76 \pm 13.3 \\
38 \pm 5.5 \\
36 \pm 6.8 \\
31 \pm 7.2 \\
32 \pm 7.2 \\
38 \pm 7.3\end{array}$ \\
\hline
\end{tabular}

${ }^{a}$ Standard deviations (SD) were calculated as the square root of the sum of between strain variance and mean within strain variance.

${ }^{b}$ Excluding homologous reactions.

like group. The percent DNA relatedness of Serratia spp. to the 38-like species is generally considered to be at the genus level $(3,4)$. In a numerical taxonomic study (16), strain 38 clustered with $S$. marcescens, $S$. liquefaciens, $S$. plymuthica, and S. marinorubra at $70 \%$ similarity level (unweighted average linkage clustering). Furthermore, strains 38 and 1073 were susceptible to several Serratia phages, whereas five Citrobacter-like strains were resistant (F. Grimont, unpublished data). We conclude that the 38-like species may reasonably belong to the genus Serratia.
We found no description in the literature that fits the 38-like species. We therefore treat it as a new species to be called $S$. odorifera species novum (Latin feminine adjective odorifera: bringing odors, fragrant). We designate strain 1073 (ICPB 3995) as the type strain for S. odorifera.

This new species may be of clinical significance in view of the source of strains studied (Table 1). With commercial identification systems, $S$. odorifera may look like atypical (gelatin-positive, anaerogenic) Enterobacter aerogenes. However, the typical odor of $S$. odorifera 
cultures should help to make a correct identification. The ability of $S$. odorifera strains to grow on caprylate-thallous agar (26) makes selective isolation possible (together with other Serratia spp.) in epidemiological and ecological studies.

DNA relatedness studies on Citrobacter-like strains were previously reported (27). This organism is certainly most closely genetically related to Serratia. Phenotypically it is closer to Citrobacter. H. Leclerc (personal communica-' tion) is presently examining a large number of strains both phenotypically and genetically.

\section{Description of Serratia odorifera sp. nov.}

Type strain. Grimont 1073, CDC 1979-77, ICPB 3995. Isolated from human sputum.

Cell characteristics. Gram-negative, peritrichous, nonsporeforming, straight rods resembling other Enterobacteriaceae. A thin capsule is occasionally observed.

Surface colonies. Surface colonies on nutrient agar are whitish, often iridescent, and slightly mucoid. Colony diameter is about 2 to $2.5 \mathrm{~mm}$ after overnight growth. Growth on agar media gives off a musty, potato-like odor. Colonies on horse blood agar are nonhemolytic.

Broth. Turbid; may form a white ring at surface or slight pellicle; gray sediment.

Growth factor requirements. There is no growth factor requirement.

Culture conditions. Facultatively aerobic; good growth occurs at temperatures between 4 and $40^{\circ} \mathrm{C}$. Growth on caprylate-thallous selective medium for Serratia.

Nutritional abilities. The following carbon sources are utilized: aconitate, adonitol, D-alanine, L-alanine, 4-aminobutyrate, L-arabinose, caprylate, D-cellobiose, D-glucosamine, kynurenate, maltose, $\mathrm{D}$-melibiose, mucate, nicotinate, $\mathrm{L}$ proline, putrescine, L-rhamnose, $D$-sorbitol, $D$ tartrate, trigonelline, and L-tyrosine. The following carbon sources are not utilized: D-arabitol, benzoate, betaine, DL-carnitine, histamine, 3-hydroxybenzoate, 4-hydroxybenzoate, $\alpha$-methylglucoside, and quinate. Utilization of $m$-erythritol, L-ornithine, and sucrose serves to differentiate biotypes.

Biochemical characteristics. No oxidase, tetrathionate reductase, phenylalanine deaminase, or arginine dihydrolase (or decarboxylase). Presence of $\beta$-galactosidase ( $o$-nitrophenyl$\beta$-D-galactopyranoside test), $\beta$-xylosidase, and lysine decarboxylase. Malonate broth unchanged. Indole produced weakly. $\mathrm{H}_{2} \mathrm{~S}$ not produced from thiosulfate. Urea not hydrolyzed. Nitrates reduced into nitrites. Gelatin liquefied, DNA hydrolyzed. Corn oil and Tween $\mathbf{4 0}$ slowly and irregularly hydrolyzed. Chitin, pectate, and Tween 80 not hydrolyzed. Reducing compounds produced from gluconate. Acid from glucose in the presence of iodoacetate. Acid from arabinose, cellobiose, glucose, inositol, maltose, mannitol, mannose, melibiose, rhamnose, salicin, sorbitol, trehalose, and xylose. Acid slowly produced from lactose. No acid from D-arabitol, dulcitol, and $\alpha$-methylglucoside. No gas from glucose. Methyl red test positive. Acetylmethylcarbinol produced (Voges-Proskauer test variable according to the technique). Two biotypes differ by ornithine decarboxylase and fermentation of sucrose and raffinose.

Habitat. Found in human clinical specimens and in food.

\section{ACKNOWLEDGMENT}

During the period this study was effected, P. A. D. Grimont was the recipient of a Bourse de Recherche du Ministère des Affaires Etrangères (France).

\section{REPRINT REQUESTS}

Address reprint requests to: P. A. D. Grimont, Service des Entérobactéries, Institut Pasteur, F-75724 Paris Cedex 15, France.

\section{LTTERATURE CITED}

1. Bascomb, S., S. P. Lapage, W. R. Willcox, and M. A. Curtis. 1971. Numerical classification of the tribe Kleb. sielleae. J. Gen. Microbiol. 77:291-315.

2. Breed, R. S., E. G. D. Murray, and A. P. Hitchens (ed.). 1948. Bergey's manual of determinative bacteriology, 6 th ed. The Williams and Wilkins Co., Baltimore.

3. Brenner, D. J. 1973. Deoxyribonucleic acid reassociation in the taxonomy of enteric bacteria. Int. J. Syst. Bacteriol. 23:298-307.

4. Brenner, D. J., G. R. Fanning, K. E. Johnson, R. V. Citarella, and S. Falkow. 1969. Polynucleotide sequence relationships among members of the Enterobacteriaceae. J. Bacteriol. 98:637-650.

5. Brenner, D. J., G. R. Fanning, A. Rake, and K. E. Johnson. 1969. A batch procedure for thermal elution of DNA from hydroxyapatite. Anal. Biochem. 28: 447-460.

6. Brenner, D. J., G. R. Fanning, F. J. Skerman, and S. Falkow. 1972. Polynucleotide sequence divergence among strains of Escherichia coli and closely related organisms. J. Bacteriol. 109:953-965.

7. Crosa, J. H., A. G. Steigerwalt, G. R. Fanning, and D. J. Brenner. 1974. Polynucleotide sequence divergence in the genus Citrobacter. J. Gen. Microbiol. 83:271-282.

8. Edwards, P. R., and W. H. Ewing. 1972. Identification of Enterobacteriaceae, 3rd ed. Burgess Publishing Co., Minneapolis.

9. Ewing, W. H., B. R. Davis, M. A. Fife, and E. F. Lessel. 1973. Biochemical characterization of Serratia liquefaciens (Grimes and Hennerty) Bascomb et al. (formerly Enterobacter liguefaciens) and Serratia rub. idaea (Stapp) comb. nov. and designation of type and neotype strains. Int. J. Syst. Bacteriol. 23:217-225.

10. Ewing, W. H., B. R. Davis, and J. G. Johnson. 1962. The genus Serratia: its taxonomy and nomenclature. Int. J. Syst. Bacteriol. 12:47-52.

11. Ewing, W. H., B. R. Davis, and iR. W. Reavis. 1959. Studies on the Serratia group. Center for Disease Control, Atlanta, Ga. 
12. Fulton, M., C. E. Forney, and E. Leifson. 1959. Identification of Serratia occurring in man and animals. Can. J. Microbiol. 5:269-275.

13. Grimes, M., and A. J. Hennerty. 1931. A study of bacteria belonging to the subgenus Aerobacter. Sci. Proc. Roy. Dublin Soc. 20:89-97.

14. Grimont, P. A. D., and H. L. C. Dulong de Rosnay. 1972. Numerical study of 60 strains of Serratia. J. Gen. Microbiol. 72:259-268.

15. Grimont, P. A. D., F. Grimont, and H. L. C. Dulong de Rosnay. 1977. Characterization of Serratia marces. cens, S. liquefaciens, S. plymuthica and S. marinorubra by electrophoresis of their proteinases. J. Gen. Microbiol. 99:301-310.

16. Grimont, P. A. D., F. Grimont, H. L. C. Dulong de Rosnay, and P. H. A. Sneath. 1977. Taxonomy of the genus Serratia. J. Gen. Microbiol. 98:39-66.

17. Leclerc, H., and R. Buttiaux. 1965. Les Citrobacter. Ann. Inst. Pasteur (Lille) 16:67-74.

18. Lehmann, K. B., and R. Neumann. 1896. Atlas und Grundriss der Bakteriologie und Lehrbuch der Speciellen bakteriologischen Diagnostik. Teil 2. Lehmann, Munich.

19. McConaughy, B. L., and B. J. McCarthy. 1970. Related base sequences in the DNA of simple and complex organisms. VI. The extent of base sequence divergence among the DNAs of various rodents. Biochem Genet. 4:425-446.
20. Martinec, T., and M. Kocur. 1961. Taxonomická studie rodu Serratia. Folia Fac. Sci. Nat. Univ. Purkynianae Brunensis. 2:1-77.

21. Richard, C. 1972. Méthode rapide pour l'étude des réactions de rouge de méthyle et Voges-Proskauer. Ann. Inst. Pasteur (Paris) 122:979-986.

22. Richard, C., B. Joly, J. Sirot, G. H. Stoleru, and M. Popoff. 1976. Etude de souches de Enterobacter appartenant à un groupe particulier proche de $E$. aerog enes. Ann. Microbiol. (Inst. Pasteur) 127 A:545-548.

23. Sakazaki, R. 1974. Genus IX. Serratia Bizio 1823, 288, p. 326. In R. E. Buchanan and N. E. Gibbons (ed.), Bergey's manual of determinative bacteriology, 8 th ed. The Williams and Wilkins Co., Baltimore.

24. Sneath, P. H. A., and V. B. D. Skerman. 1966. A list of type and reference strains of bacteria. Int. J. Syst. Bacteriol. 16:1-133.

25. Stapp, C. 1940. Bacterium rubidaeum nov. spec. Zentralbl. Bakteriol. Parasitenkd. Infektionskr. Hyg. Abt. 2 102:251-260.

26. Starr, M. P., P. A. D. Grimont, F. Grimont, and P. B. Starr. 1976. Caprylate-thallous agar medium for selectively isolating Serratia and its utility in the clinical laboratory. J. Clin. Microbiol. 4:270-276.

27. Steigerwalt, A. G., G. R. Fanning, M. A. Fife-Asbury, and D. J. Brenner. 1976. DNA relatedness among species of Enterobacter and Serratia. Can. J. Microbiol. 22:121-137. 